\title{
Influence of Intelligence and Gender on Academic Achievement of Secondary School Students of Lucknow City
}

\author{
Ritu Chandra* and Dr. (Prof.) Sheikh Azimmudin** \\ *Research Scholar,Faculty of Education, Integral University, Lucknow (India) \\ **Professor, Faculty of Education, Integral University, Lucknow (India)
}

\begin{abstract}
This present study examines the influence of Intelligence and gender on Academic achievement of secondary school students of Lucknow city. The sample of the study consisted of 614 students (358 males and 256 females) from ninth and tenth class of fourteen schools of Lucknow city of Uttar Pradesh (India). Intelligence was measured by Dr.G.C.Ahuja's Group Test of Intelligence. The board Results of Class X was used for collecting data for academic achievement. The findings of the study reveal that there is a significant influence of Intelligence on academic achievement whereas gender has not significantly influenced the academic achievement .T-Test; ANOVA and F-value were used for analyzing the data.
\end{abstract}

Keywords: Academic Achievement, Gender, Intelligence

\section{Introduction}

With a change in scenario and thrust on modern materialistic achievement, the education has undergone a drastic change. A person's education has become an indicator of his status in society. The scores in examination decide about the level of intelligence whereas the education is linked to the life chances, income and well being (Battle Lewis, 2002). In our society academic achievement is considered as a key criterion to judge one's total potentiality and capacity. Hence academic achievement occupies a very important place in education as well as in the learning process. Studies repeatedly show that the performance on intelligence tests is correlated with school achievement (N.Brody, 1997; Gustafsson \& Undheim, 1996; Sattler, 2001). As far as intelligence is concerned, males and females appear to be equal. The differences are related to specific abilities or specific traits. Males on an average show superiority over females in the ability to reason and to detect similarities in certain aspect of general information. Girls on an average show some superiority in memory, language and aesthetic comparisons. Alan Feingold (1992) focused on male-female differences in average performance and observed that males score higher than females on tests of general knowledge mechanical reasoning and females scored higher than males on tests of language usage. There was no notable sex differences in general verbal ability, abstract reasoning and memory span.

The intelligence is a concept which has affected the life of every individual in all spheres of life. It is responsible for the academic outcome and finally the success in life. It helps us in combating the challenges of life and be a winner. There are individual differences in educational outcomes and to predict these differences, the first broad test of cognitive ability (Binet 1905 Zenderland 1998) was developed. Zimmerman, Barbara, Zaman (1981) did a study of individual differences and learning and an important implication of the study was that there are hereditary factors which are responsible for one's intelligence. The intellectual development at any stage is the inheritance from parents and sharing of experiences due to environmental exposures. Since we cannot control or modify the genetic factor hence a conducive environment must be provided for the intellectual development of the children. A child can make use of his intellectual capacities to the optimum if he gets a conducive environment.

\section{Previous Studies}

Extensive researches have been conducted to examine the role of various factors on academic achievement. According to Watkins, Lei \& Canivez (2007), some researches show intelligence and academic achievement as highly correlated, others believe that it is reciprocal. Some believe that it is casually related to achievement . Radha Rahi (1992) revealed that sex differences existed in Academic achievement and boys and girls showed a non-significant positive relationship between intelligence and work activity. Archana Agarwal (2002) studied some correlates of Academic achievement and a significant positive relationship was found between academic achievement and intelligence. Brunietal (2006) examined the relationship between academic achievement and demographic and psychology factors. The finding of the study indicated significant differences between males and females. According to this study, females had higher academic achievement as compared to males. However other studies found there was no gender differences in achievement (Herbert \& stipek, 2005). Naderi, Abdullah, Hamid \& Sharir (2008) examined intelligence and gender as predictors of academic 
achievement among undergraduate Iranian students. They found that intelligemnce \& gender explain only 0.019 of the variance in academic achievement [CGPA Scores]. Partial correlations between academic achievement and IQ Scores and gender were non-significant at 0.05 . Coefficients also show there is no significance between academic achievement and IQ and gender at 0.05. Edmore Mutekwe, Maropeng, Modiba and Cosmas Maphosa (2012) conducted a study to explore girl students' perceptions of gender and academic achievement in the Zimbabwean schools. The study found that female students believe that they were not at par with boys in terms of treatment. Female high school students held certain perceptions which they believe negatively affected their academic achievement. The study recommends that gender sensitivity should be taken seriously in schools and in homes as well as in society at large for improved academic attainment. Deary, Strand, Smith \& Fernandes (2007) found a strong and positive relationship between intelligence and academic achievement.

We still find few gaps in our knowledge about relationship between Intelligence gender and academic achievement. There are studies which support a strong relationship between these three variables whereas there are other studies which have propounded against the relationship between gender, intelligence and academic achievement. The present study aims at achieving the following objectives.

1. To study the influence of gender on academic achievement of secondary school students.

2. To study the influence of intelligence on academic achievement of secondary school students.

\section{Hypotheses}

1. There is no significant difference between male and female secondary school students on academic achievement.

2. There is no significant difference between IQ and academic achievement of secondary school students.

There is no significant difference between academic achievement of high \& average IQ category secondary school students

There is no significant difference between academic achievement of average and low IQ category secondary school students

There is no significant difference between academic achievement of high and low IQ category secondary school students

\section{Justification of the study:}

Academic Achievement is the main focus of the educative process to improve the learning and performance of the students. The academic achievement is the criteria for assessing their learning outcomes. It is the process of measuring the behavioural change of the students at the end of any instruction. This parameter categorises the students as slow, average and fast learners. The performance and academic achievement of students depends on variables like type of school, socio-economic status of students, parent's education, Intelligence, personality etc. Intellectual development depends upon both environmental \& biological factors. Since the academic achievement is a strong indicator of students successful academic career, it is imperative to assess the extent to which the intelligence influences the Academic Achievement, so that children with average IQ and even low IQ could optimize their academic achievements. The findings of the study might provide necessary guidelines for enhancing the academic achievement of the secondary school students.

\section{Methodology}

The present research is descriptive in nature. It is conducted in Lucknow city, Uttar Pradesh in India. The sample comprises of 614 students (Male 358, Female 256) from 14 secondary schools of Lucknow city, Uttar Pradesh. Purposive sampling was used to collect the sample of the study. The age ranged from $13-17$ years for both males \& females. Sample was collected from 14 schools of Lucknow city

\section{Tools}

G.C.Ahuja Group Test of Intelligence for assessment of Intelligence by Dr. G.C.Ahuja (2008) and Socio-economic Status scale for assessment of (SES) Socio-economic status by Dr. Meenakshi (2004) were used. The Board results of students were recorded from school for measuring academic achievement.

\section{Results, Analysis and Discussion}

The data was analyzed on the basis of academic achievement, intelligence and gender using descriptive as well as inferential statistics. The data was analysed to compare the means of male \& female students for comparative study of academic achievement of male \& female students. Table 1 shows that there is no significant difference between academic achievement of male $\&$ female students. $(\mathrm{df}=612, \mathrm{t}=1.235)$. 


\section{Table 1}

\section{Significance of the Difference Between Means of Academic Achievement of Male and Female} students

\begin{tabular}{|c|c|c|c|c|c|}
\hline Gender & $\mathbf{N}$ & Mean & S.D. & S.Em & t-value \\
\hline Males & 330 & 67.63 & 12.089 & .666 & \multirow{2}{*}{$1.235 * *$} \\
\hline Females & 284 & 68.84 & 12.087 & .717 & \\
\hline
\end{tabular}

$\mathrm{df}=612, * *$ Not Significant

The above table shows that the total number of Males is 330. The mean score of academic achievement of males is 67.63 and S.D. is 12.089. The S.Em. of Males on academic achievement is.666. The number of Females is 284. The mean score of Females is 68.84 and S.D. is 12.087. The S.Em. of females on academic achievement is.717. The $t$-value between males and females is 1.235 at 612 degree of freedom. The value of $t$ is not significant at .05 level hence hypothesis is accepted. It means that there is no significant difference between male and female secondary school students on academic achievement. On comparing, it is found that the means of male and female students is almost the same, which also shows that there is no significant difference in their academic achievement. Since the students are of same standard Gender has not affected their academic achievement. Earlier education of girls was neglected. They were not given sufficient opportunities for improving their academic achievement. Due to more number of girls being educated and stress on girl education, similar environment and opportunities, good schools and teachers being available for girls academic achievement has become the same for males and females.

Herbert and stipek (2005) found that there was no gender difference in achievement.

A study conducted by Naderi ,Abdullah , Hamid and Sharer (2008)on intelligence and gender as predictors of academic achievement revealed that gender and intelligence are not the predictors of student academic achievement. There is no significance between academic achievement, IQ and gender at 0.05 .

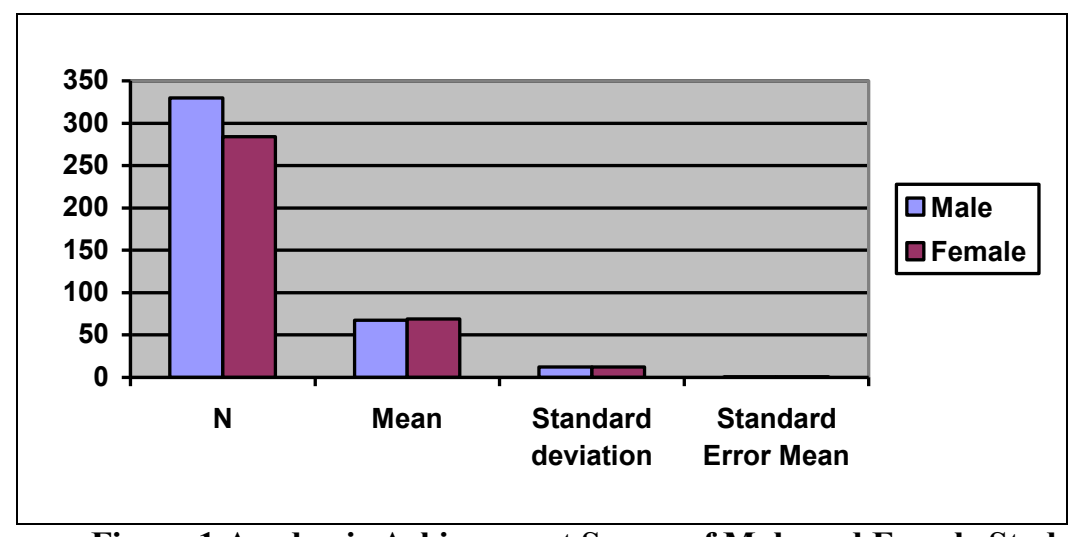

Figure 1 Academic Achievement Scores of Male and Female Students

Table 2

Significance of the Difference Between Means of Academic Achievement of High IQ and Average IQ Students

\begin{tabular}{|c|c|c|c|c|c|}
\hline IQ Category & $\mathbf{N}$ & Mean & S.D. & S.Em. & t-value \\
\hline High & 52 & 78.27 & 9.547 & 1.324 & \multirow{2}{*}{$6.543^{*}$} \\
\hline Average & 466 & 68.92 & 11.576 & .536 & \\
\hline
\end{tabular}

The above table shows that there are 52students in High IQ Category. The mean score of high IQ category students on Academic Achievement is78.27 and S.D. is 9.547. The S. Em of High IQ category on Academic achievement is 1.324.The number of Average IQ Category Students are 466. The mean score on academic achievement is 68.92 and S.D. is 11.576. The t-value between High and Average IQ Category Students is 6.543 at 516 degree of freedom.,which is significant at .05 level of significance, hence hypothesis is rejected. It means that there is significant difference between High and Average IQ Category secondary school students on Academic Achievement This table also reveals that there are more students in the average IQ category as compared to High IQ category .Due to their IQ differences the respective academic achievement also varies. The Students with High IQ have higher academic achievement. The high IQ child will grasp the concept in less time as compared to average child and will definitely perform better than the average child. Figure2 also depicts the result. 


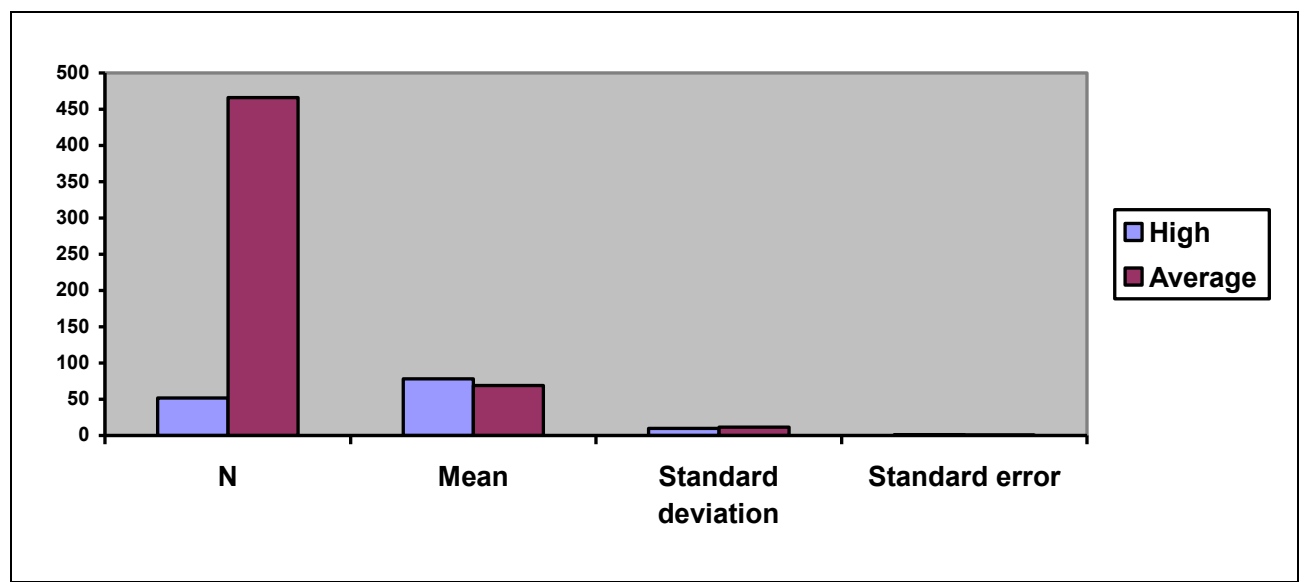

Figure 2 Academic Achievement Scores of High and Average IQ Students

Table 3

Significance of the Difference Between Means of Academic Achievement of Average IQ and Low IQ Students

\begin{tabular}{|c|c|c|c|c|c|}
\hline IQ Category & $\mathbf{N}$ & Mean & S.D. & S.Em. & t-value \\
\hline Average & 466 & 68.92 & 11.576 & .536 & \multirow{2}{*}{$8.487^{*}$} \\
\hline Low & 96 & 59.19 & 9.935 & 1.014 & \\
\hline
\end{tabular}

The above table shows that there are 466 students in Average IQ Category. The mean score for average IQ category students on Academic Achievement is 68.92 and S.D. is 11.576. The S. Em. on Academic achievement is .536. There are 96 students in Low IQ Category. The mean score on Academic achievement is 59.19 and S.D. is 9.935. The S .Em. on Academic achievement is 1.014. The t-value between Average and Low IQ Category students is 8.487 at 560 degree of freedom. The T value is significant at .05 level of significance, hence hypothesis is rejected. It means that there is significant difference between Average and Low IQ Category secondary school students on Academic Achievement. There are less number of students in low IQ category as compared to average IQ category. An average student will grasp the concept in a better way as compared to low IQ students. Hence the academic achievement of average IQ students is better than the low IQ students.

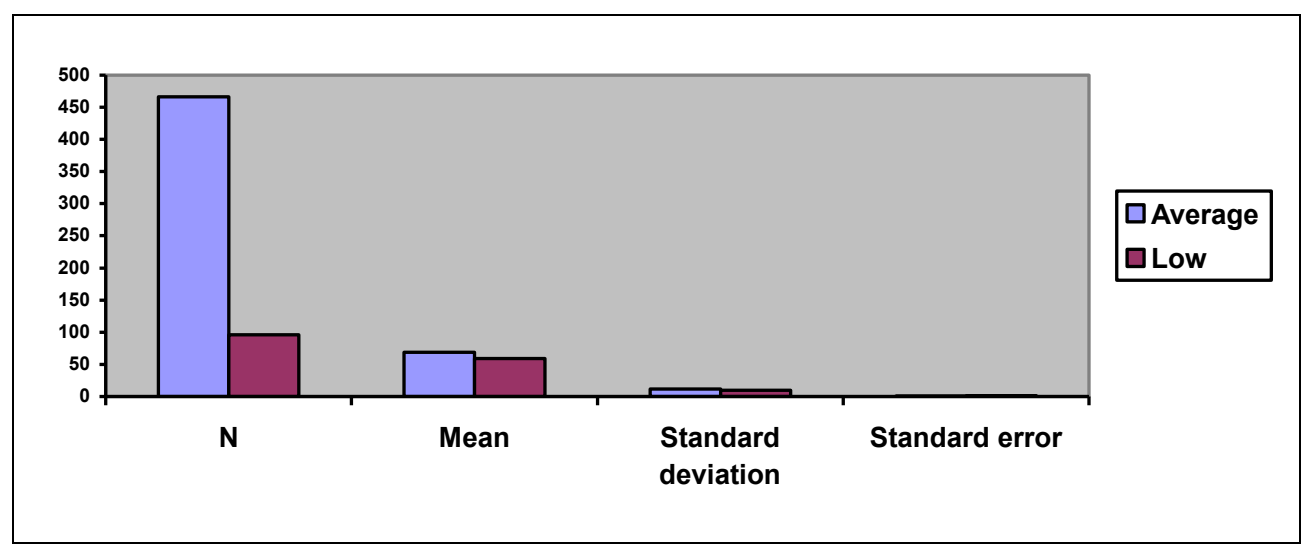

Figure 3 Academic Achievement Scores of Average and Low IQ Students

Table 4

Significance of the Difference Between Means of Academic Achievement of High IQ \& Low IQ Students

\begin{tabular}{|c|c|c|c|c|c|}
\hline IQ Category & N & Mean & S.D. & S.Em. & t-value \\
\hline High & 52 & 78.27 & 9.547 & 1.324 & $11.443 *$ \\
\hline Low & 96 & 59.19 & 9.935 & 1.014 & \multirow{2}{*}{ df $=146, *$ Significant at 5\% } \\
\hline
\end{tabular}


The above table shows that the total number of high IQ category students is 52 . The mean score on academic achievement is 78.27 and S.D. is 9.547. The S.Em. on Academic achievement is 1.324. The low IQ category number of students are 96. The mean score is 59.19 and S.D. is 9.935.The S.Em. on Academic achievement is 1.014. The t-value between high IQ and low IQ is 11.443 at 146 degree of freedom. The T- value is significant at .05 level of significance., hence hypothesis is rejected . It means that there is a significant difference between high IQ and low IQ category students on academic achievement. The result shows that academic performance needs intelligence. The students who are able to understand their studies well, grasp it well, and perform better in examinations as compared to low IQ students. The low IQ students need more time to grasp the concept as they have poor learning power and so it is obvious that their academic achievement is low. The findings of Srivastava (1980), Mehrotra (1986), Mishra (1986) also support this result that intelligence positively affects the academic achievement of the students.

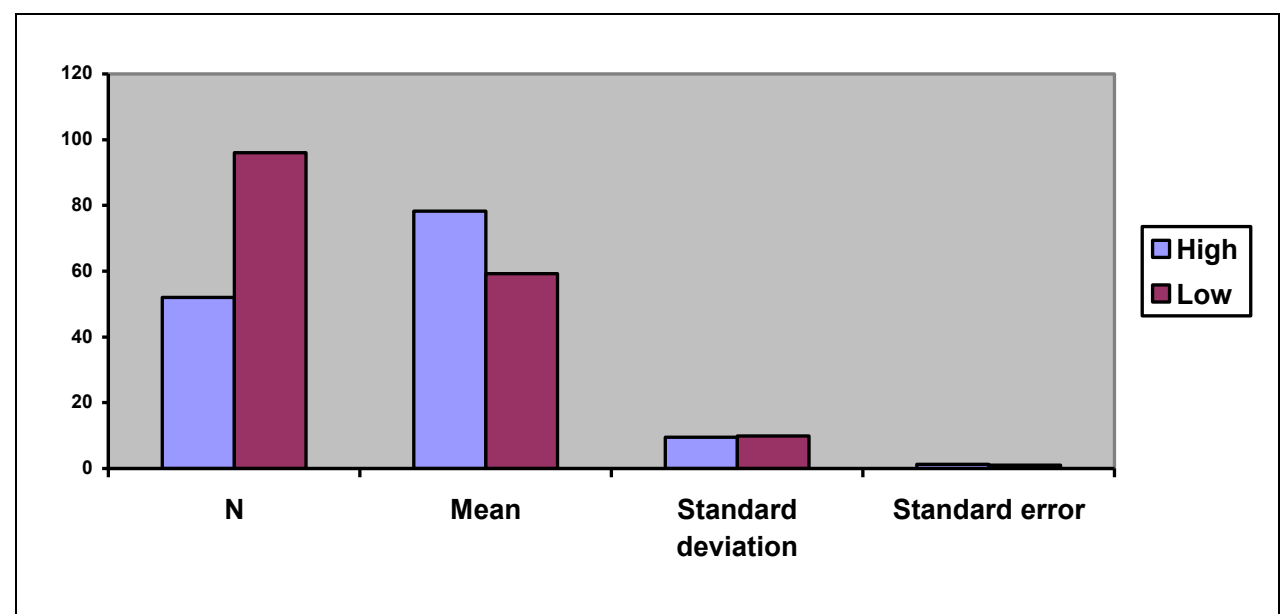

Figure 4 Academic Achievement Scores of High and Low IQ Students

Table 5

Summary of Analysis of Variance in respect to Intelligence and Academic achievement

\begin{tabular}{|c|c|c|c|c|c|}
\hline \multicolumn{6}{|c|}{ ANOVA } \\
\hline Academic Achievement & Sum of Squares & df & Mean Square & $\mathbf{F}$ & Sig. \\
\hline Between Groups & 13897.082 & 2 & 6948.541 & $56.042 *$ & .000 \\
\hline Within Groups & 75756.241 & 611 & 123.987 & & \\
\hline sTotal & 89653.322 & 613 & & & \\
\hline
\end{tabular}

Table 6

Comparison of Academic Achievement scores of Low Average and High IQ Students

\begin{tabular}{|l|c|c|c|c|c|c|}
\hline & & & & \multicolumn{3}{|c|}{ T- Value } \\
\cline { 5 - 7 } Variable & $\mathbf{N}$ & Mean & Standard Deviation & High & Average & Low \\
\hline High IQ & 54 & 78.24 & 9.371 & ----- & 6.543 & 11.443 \\
\hline Low IQ & 458 & 69 & 11.605 & 6.543 & ------ & 8.487 \\
\hline Total & 102 & 59.25 & 9.727 & 11.443 & 8.487 & ------ \\
\hline
\end{tabular}

Table 5 compares the Academic Achievement scores of High, Average \& Low IQ students. The total numbers of students in Low IQ category are 102, in Average IQ category are 458 \& in High IQ category are 54. The mean value of Academic Achievement for Low IQ is 59.25\% while for Average IQ is 69\%, whereas for High IQ it is $78.24 \%$. The Standard Deviation for Low IQ is $9.727 \%$, for Average IQ it is $11.605 \%$ and for High IQ students it is $9.371 \%$. The F Value in Table 6 is highly significant at 56.042 . The null hypothesis is rejected. Hence there is a significant influence of Intelligence on Academic Achievement.

\section{Findings and Conclusions}

The finding of the study is that there is no influence of gender on academic achievement. Since girls are going to same schools and exposed to similar environment and similar teachers. They receive same level of 
education. Initially decades back, female children were made to do household works and look after younger siblings. They were made to help out in household chores. But now the time has changed. Equal opportunity and status is being provided to the girl child as well. She is provided facilities like tuitions and coaching for her academic excellence. Hence no difference is found between the male and female child in relation to educational opportunities. That is why gender has no influence on academic achievement.

The result of the study reveals that intelligence influences the academic achievement of the student. The child with High IQ has better academic achievement than the child with Average IQ. The high IQ Child will have better grasping power, retention, recall and higher understandability as compared to an average child. So he will definitely perform better in academics. A bright child will get high marks and will show good performance. The results of the study show that the average IQ children perform better than the low IQ children. The average IQ child will be better learner in comparison to a slow learner. Hence the academic achievement of Average IQ child will be higher than the Low IQ child.

The result of the study shows that the High IQ child will score better than the Low IQ child. Low IQ child will be a slow learner. A child with high IQ is fast learner. He will understand, grasp and learn the concepts in a better way. Academic performance needs intelligence.

\section{Limitation of the Study}

The study is limited to Lucknow city of Uttar Pradesh in India; hence the results cannot be generalized. In a short span of time it is not possible to cover all the variables. Due to shortage of resources the study was limted to 14 secondary schools only.

\section{References:}

[1]. Phillip L Ackerman, David F Lohman, (1996) Handbook of Educational Psychology, Lawrence Erlbaum Associates , Publishers, London

[2]. Zebun Nisa Khan(2005), 'Scholastic Achievement of Higher Secondary students in Science stream', India Journal of Social Science ( 92) 84-87

[3]. Damon clark,(2007), 'Selective schools and Academic Achievement'. Ph.D., Thesis, Florida University, 3182,1 - 4.

[4]. Goswami. R. (1982). 'An Enquiry into Reading Interests of the Pupils of Standard VII to X in Relation to Intelligence', SES and Academic Achievement. Doctoral Dissertation, M. S. University, Baroda.

[5]. Mohammad Iqbal Mattoo (2011), 'Vocational Interests and Academic Achievement of Secondary School students at different levels of creative thinking ability - a comparative study', Indian Educational Review, 49 (2), 117-129

[6]. Ian J. Deary, Steve Strand, Pauline Smith, Cres Fernandes, (2006), 'Intelligence and educational achievement', Elsevier, ScienceDirect Intelligence, 35 (2007) 13-21

[7]. Watkins, Lei and Canivez (2007) 'Psychometric Intelligence and Achievement: A cross lagged panel analysis', Elsevier, ScienceDirect Intelligence, 35 (2007) 59-68

[8]. Rani, Radha (1992), 'A Study of Intelligence, Socio-Economic Status, Achievement - Motivation and Academic Achievement with reference to pupil's behavior in classroom', Ph.D thesis in Education, Agra University

[9]. Archana Agarwal, (2002), 'Some correlates of Academic Achievement', Indian Journal of Educational Research, 21 (2), $75-76$

[10]. Herbert \& Stipek (2005), 'The emergence of gender differences in children's perceptions of their academic competence' Journal of Applied Developmental Psychology, 26 (3), 276-295

[11]. Habibollah Naderi, Rohani Abdullah, Tengku Aizan Hamid, Jamaluddin Sharir (2008) 'Intelligence and Gender as Predichors of Academic Achievement Among Undergraduate Students'. European Journal of Social Science, 7, 199-200

[12]. Edmore Mutekwe, Maropeng Modiba and Cosmas Maphosa, (2012), 'Female Students' Perceptions of Gender and Academic Achievement: A Case of Sixth Form Girls in Zimbabwean School', Journal of Social Science, 32(1): 111-120

[13]. Ian J. Deary, Steve Strand, Pauline Smith, Cres Fernandes, (2007) 'Intelligence and educational achievement' Elseiver, Intelligence $35,(1), 13-21$

[14]. Mehrotra S (1986), 'A Study of the Relationship between Intelligence, Socio-Economic Status, Anxiety, Personality Adjustment and Academic Achievement of High School Students', Ph.D thesis, Education, Kanpur University

[15]. Srivastava (1974), “An investigation in to the factor related to under achievement" Doctoral dissertation, Patna University

[16]. Misra, M, (1986) 'A Critical Study of the Influence of Socio-Economic Status on Academic Achievement of Higher Secondary Students in Rural and Urban Areas of Kanpur’ Ph.D thesis, Education, Kanpur University 